\title{
JGBA-272824
}

\section{A Review of The Relationship Between \\ Leadership Style and Innovation: Insights and Directions for Future Research}

\author{
By: \\ Dr. Lavanya Rastogi, \\ Visiting Professor \\ Salford University, \\ UK \\ lavanay.rastogi@gmail.com \\ Prof. Hassan Yazdifar \\ Professor \\ Salford University, \\ UK \\ $\underline{\text { H.Yazdifar@salford.ac.uk }}$ \\ Dr. Ashraful Alam, \\ Lecturer \\ Salford University, \\ UK \\ M.A.Alam@salford.ac.uk \\ Dr. Rasol Eskandari, \\ Lecturer \\ Salford University, \\ UK \\ R.Eskandari@salford.ac.uk \\ Dr. Mohammad Al Bahloul \\ Lecturer \\ Salford University, \\ UK \\ M.AlBahloul@salford.ac.uk
}




\begin{abstract}
This chapter aims to critically reflect on the available literature on leadership style and innovation, and especially to assess the linkages between these variables. It starts with an overview of leadership studies, tracing the historical emergence and development of leadership theories, from the Great Man theory, trait theory and leader behaviour theory to situational and contingency theories of leadership. It then delves deeply into the transformational theory, owing to the vast amount of research focus that appears to be dedicated to this theory. The chapter critically analyses the scope of transformational theory, and explores the gaps that may need refinement in order for the theory to remain relevant in the current, 21st Century, business environment. The chapter also discusses innovation theory and literature related to different perspectives on innovations, including the radical and disruptive views, the ambidextrous perspective, design thinking, open, lean and horizontal models, and their impacts on organizational performance. The chapter then turns to explore the linkages between managing innovation, leadership style and organizational performance. The review in this chapter adds to the existing literature and provides support for the contention that innovation impacts organizational performance, while leadership has a moderating impact on this relationship.
\end{abstract}




\section{Introduction}

The $21^{\text {st }}$ century has already seen tumultuous and drastic economic events that have destroyed economies and business structures across the globe, and have revealed failures of leadership at various levels (Gilpin, 2018). In the age of information technology, inter- and intra-firm connections, as well as networks and linkages with external environmental agencies, are instantaneous and overwhelming (Lee, 2016). Now, businesses have to deal with an unprecedented amount of data and information, and have to operate in a dynamic environment dominated by complex and intricate relationships between various stakeholders (Shapiro \& Stefkovich, 2016). The Internet has taken the concept of connectivity to a new level by moving data generation and information sharing beyond the realm of control (Lee, 2016), with the plausible positive impact of greater propensities for innovation (Shapiro \& Stefkovich, 2016), as it has enabled the deployment of virtual teams and harnessing of online resources like never before. However, the fact that the world is so very connected also exposes businesses to novel, exotic and unfathomed vulnerabilities and impacts. For example, it is only now that we are realizing the economic impact of the environmental crisis, or of social discrimination, and businesses are forced to consider how they manage their processes and people (Laszlo \& Cescau, 2017).

It is probably simply too much to presume that leadership styles and skills that functioned well during the comparatively placid era of the past century could continue to be relevant in the current one. While the transformational leadership style continues to be proposed as the most suitable candidate for the $21^{\text {st }}$ Century (Lewis, Boston \& Peterson, 2017), there are indications that this theory too needs to be refined to fit better into the realities of the current century. This review of literature therefore aims first to develop a review of early theories of leadership, including transformational and transactional theories, conducting a critical evaluation of transformational theory in particular, in order to point out the areas of refinement; and then to develop an understanding of innovation as a measurable outcome of leadership, or more specifically, of the transformational leadership style. This 
chapter also discusses the theory of innovation, and presents a review of research linking organizational performance, innovation and leadership. The chapter then moves on to develop a sense of how these variables operate and the nature of the relationship between them, and finally concludes with a section on how innovation and organizational performance can be improved by using a refined version of transformational leadership.

The discussion that follows traces the evolution of the Leadership theories in recent decades, especially in the post-industrialization world, where the value of labour has been slowly replaced by the value of skill. This discussion does not differentiate between theories that evolved from the study of human behaviour or psychology and those that evolved from pressure on the efficiency and productivity of knowledge workers. This segue of conversation leads us into the discussion of innovation and how it has interacted with leadership in the workplace.

It is interesting to note that the evolution of theories (about both leadership and innovation) does not have strict boundaries; tenets/features of one easily blend and bleed into a subsequent theory. Hence, the review mostly reflects organizer efforts around theories rather than very distinctly different theories, as one would expect in the study of disciplines like economics or science.

\subsection{Great Man Theory and Trait Theory of Leadership}

Great Man Theory was built on the premise that specific individuals had certain inherent qualities (Dowd, 1936). It was based on the belief that leaders are exceptional people, born with innate qualities and destined to lead. The use of the term 'man' was intentional because until the latter part of the twentieth century, leadership was thought of primarily as a male domain, especially in the context of the military and Western penmanship (Dowd, 1936). Leadership was considered as a complex phenomenon, integrated within the psyche and personality of the leader. These theories were probably the result of researchers considering the numerous charismatic leaders of the era. 
Trait Theory of leadership closely resembled this premise, but seemed to deconstruct the actual process of leadership and link it to the leaders' inherent traits. Scholars have focused on developing a list of traits or qualities associated with leadership, and seem to have drawn on virtually all the adjectives in the dictionary that describe some positive or virtuous human attribute - from ambition to zest for life (Bernard, 1926; Bingham \& Davis, 1927; Tead, 1935; Kilbourne, 1935). Both these theories are based on the premise that some individuals are born with a set of characteristics that make them a leader; and as such, in effect, leadership cannot be learnt, but must be innate. The assumption here was that leaders, genetically or by birth, possessed superior traits and characteristics that differentiated them from the masses. Although both these theories were developed from exhaustive studies of real-life leaders; they appear to qualify people into distinct categories - born leaders or masses - which could form the basis of and lead to discrimination against a section of society that was not deemed to have those special traits or characteristics.

\subsection{Behavioural Theory of Leadership or Leadership Style Theory}

The style approach to leadership was the focus of research during the late 1940s and early 1950s. In terms of this approach, the focus shifted from leadership traits to patterns of behaviour or leadership styles. One theory of leadership style, based on the Michigan and Ohio State Studies (Bolden, Gosling, Marturano \& Dennison, 2003), discriminates between leaders who are task-oriented and those who are people-oriented. Another theory added a third dimension to the task and relationship orientation of leaders; this was participative leadership, where the leaders encouraged and empowered followers to become part of the leadership process (Bolden et al., 2003).

These theories make a case for what leaders actually do as part of their leadership process, rather than for any inherent traits or qualities that they may possess. Different patterns of behaviour are observed and categorized as 'styles of leadership'. This theory has probably attracted the most attention from practicing managers (Bolden et al., 2003), as a 
considerable body of literature exists on leadership styles (task orientation vs. people orientation). Moreover, the style theory of leadership continues to inform the later theories like transformational and transactional theories of leadership (Bolden et al., 2003).

\subsection{Psychological Theories of Leadership (Leader Role Theory)}

Closely associated with the leadership style theory is the leader role theory, which is rooted in the works of psychoanalysts like Freud (1921) and Fromm (1941), who compared the leadership role with that of a father who is a source of both fear and love. Mintzberg (1973), Larson, Hunt and Osborn (1976) and Jermier and Berkes (1979) believed that the individual and the situation interact in such a way as to allow one or even a few individuals to emerge as leaders. This theory had inherent difficulty, as many of its constructs and assumptions were rooted in the psychological thinking of its time and could not be assessed or measured empirically. It also lagged in developing a comprehensive understanding of how leaders are able to strike a balance between love (motivation) and fear, and whether such an approach is effective in the context of organizations (Jermier \& Berkes, 1979).

\subsection{Humanistic Theories of Leadership}

Humanistic theories assumed that humans are, by nature, motivated beings, and that organizations are, by nature, structured and controlled. Leadership should modify organizational constraints so that the full potential of employees and the organization may be facilitated. Argyris (1957; 1962; 1964), McGregor (1960), Likert (1967), Blake \& Mouton (1964), Maslow (1954) and Hersey and Blanchard (1982) all contributed to these humanistic schools of thought. Evans $(1970)$ and House $(1971 ; 1977)$ formalized the path-goal theory, in terms of which leaders reinforce change in their followers by displaying certain behaviour. Goals are clarified and employees are encouraged when they perform well. Most leadership theories of this genre aim to provide guidelines to make workplaces more conducive to motivating employees and to enable leaders to modify their styles to fit their employees' 
needs (Evans, 1970). A review of humanistic theories reveals that much of the emphasis had shifted from the leader to the follower: the leadership process is now geared toward understanding how best to lead the employees, rather than focusing on what leaders do or possess.

\subsection{Situational Leadership Theories}

Situational leadership theories, as described by Bogardus (1934), Hocking (1924), and Hersey and Blanchard (1982), contend that leadership is the product of situational demands. A great leader will be the result of time, place and circumstance. According to Hersey and Blanchard (1982), the suitability of leadership is a result of the leaders' style and the followers' preparedness or maturity level. Similarly, Goleman (cited in Goleman, Boyatzis \& McKee, 2013) developed a situational leadership theory that matched an appropriate leadership style (out of six) to the emotional intelligence of followers. Vroom and Yetton's Normative Decision Theory underscores the fact that situations need to determine the amount of time a leader needs to spend on a decision and the number of people he or she needs to involve in decision-making (Vroom \& Yetton, 1973). These theories again shifted the focus from leaders, or even followers, to the situation or the context within which leadership occurs. While providing insights about how extraneous factors (other than the presence of leaders and followers) impact on a leaders' ability to lead, these theories also brought into focus the need for flexibility in any leadership approach.

\subsection{The Contingency Approach to Leadership}

The contingency approach to leadership, which is found in the works of Fiedler (1967) and Fiedler, Chemers and Mahar (1976), viewed the effectiveness of a task- or relations-oriented leader as contingent on the situation. This is a refinement of the situational viewpoint and focuses on identifying the situational variables which best predict the most appropriate or effective leadership style to fit the particular circumstances (Fiedler, 1967; Fiedler, Chemers \& Mahar, 1976). This approach further enhanced the case 
for adopting flexibility in the leadership approach to suit the needs and demands of the situation.

\subsection{Transformational Leadership}

Transformational leadership was first mentioned as an idea in 1973, in the sociological study conducted by Downton (1973), "Rebel Leadership: Commitment and Charisma in the revolutionary process". After that, James McGregor Burns (1978) used the term "transformational leadership" in his book Leadership. Bass (1985) formalized the transformational leadership theory, which also explained the models and factors of behaviour. A year later, in 1986, Tichy and Devanna published a book under the title "The Transformational Leader."

Burns (1978) explained transformational leadership as a process wherein leaders and followers engage in a mutual process of raising one another to higher levels of morality and motivation. Transformational leadership focuses on superior leadership performance, which occurs when leaders broaden and elevate the interests of their employees, generate awareness and acceptance of the purpose and mission of the group, and when they steer their employees to look beyond their self-interest for the good of the group (Bass, 1990). Bass and Steidlmeier (1999) revised the transformational leadership theory to include leaders' moral behavior. Also, transformational leadership was linked with leaders' intention to develop a shared set of values and culture for moral behaviors.

Through research in the field of leadership, Tichy and Devanna (1986) arrived at an understanding of a set of characteristics that entail transformational leadership. Most scholars agree that these characteristics or behaviours are reflective of transformational leadership. Tichy and Devanna (1986) found that transformational leaders have qualities of agents of change, display courage, show openness and faith in their followers, lead by values, and have life-long learning ability, the ability to face complex, ambiguous and uncertain situations, and visionary abilities. 
According to Bass and Avolio (1994), transformational leaders display behaviours associated with five transformational styles:

1) Idealized Behaviours - they live in accordance with their ideals;

2) Inspirational Motivation - they are inclined to inspire others through their thoughts and actions;

3) Intellectual Stimulation -they are able to stimulate others through their own behaviours, thoughts and intentions;

4) Individualized Consideration -they display the tendency to coach and develop others;

5) Idealized Attributes -they are focused on building a workplace that is full of respect, trust and faith.

It is evident that several of Bass and Avolio's (1994) characteristics overlap with those of Tichy and Devanna (1986). Also, several additional aspects of transformational leadership have been explored and added to the literature on this theory. For example, transformational leadership is asserted to be the result of greater cognitive differentiation (Kuhnert \& Lewis, 1987), which some leaders have and which enables them to have a realistic perception of situations. This contention again implies that transformational leadership may be an inherent characteristic or trait, and plausibly cannot be learnt or developed by people who are lower in cognitive differentiation. McCall (1998) relates this concept of leadership development to executivelevel leaders. According to McCall (1998), while leaders may be born or made, what is more important is that they continue to learn, grow and change. As such, it can be said that leadership, including transformational leadership, is the product of developmental experiences in the leader's life, from childhood up to the present (Boamah, Laschinger, Wong, \& Clarke, 2018).

Fisher (1986) found that leaders who are flexible and adaptable are better at transformational leadership. This indicates a leader's inherent or 
learnt ability to change his approach in dealing with different types of employees or situations (Fisher, 1986). Also, Fisher (1986) found that transformational leaders are interested in developing followers and they move people from basic security concerns to deeper concerns associated with personal and corporate growth and development. While transformational leadership behaviours are easily visible and probably measurable, it is not clear whether such behaviours are learnt or are part of the leaders' internal value system or inherited traits. Literature that could deconstruct the actual motivation or inherent thought process of transformational leaders is lacking (Triana, Richard \& Yücel, 2017), although there is an abundance of research on how transformational leadership is expressed and its effectiveness in the organizational context (Triana et al., 2017).

This summary of transformational leadership also implies that people need to have certain inherent propensities or inclinations (being interested in people's needs). The transformational leader's ability to connect with followers on a deeper level has not been widely explored, and suggests a need to better understand the internal motivations of the transforming leader (Triana et al., 2017; Eberly, Bluhm, Guarana, Avolio, \& Hannah, 2017). Moreover, like other theories of leadership, transformational leadership theory is rooted in the presumptions (and research based on analysis of real leaders of the era) that personal characteristics or behaviours of leaders' interplay with situational demands. Like earlier theories, transformational leadership theory also does not seem to take into consideration some "untypical" qualities of leaders of those days (Caniëls, Semeijn, \& Renders, 2018). These "new" qualities, especially in the context of the $21^{\text {st }}$ century, require a new theory or a new leadership concept. This is especially true in the business world, which has witnessed a paradigm shift and revolutionized the way business is carried out. All boundaries have practically disappeared, owing to the instant communications and instant transfers of money and other resources, and a complete transformation has taken place from a business environment that operated 
across segmented national boundaries to an ecosystem that consists of interlinked global systems (Boamah et al., 2018). These changes have brought about novel organizational structures and networks, which in turn require new leadership styles and behaviours to manage them.

Organizations today have to operate within a highly competitive global economic environment and are struggling for their survival and growth due to both enhanced connectivity of global markets and wider choices available to the customers. Radical discontinuity is becoming endemic worldwide (Tsvetkova, Thill, \& Strumsky, 2014). The Information Technology revolution, a key to knowledge-driven businesses, has further fundamentally altered the way organizations work (Glor \& Rivera, 2016). Information technology, coupled with free markets, has eroded most of the national trade boundaries, and has led to unprecedented competition (Schaltegger, Lüdeke-Freund, \& Hansen, 2016). Organizations are no longer immune to international trends in efficiencies and quality and need to demonstrate sustainable performance. Globalization, deregulation and digitalization are ushering in new benchmarks and new pressures for organizations (Tang \& Yeh, 2013). These drastic environmental changes are putting unprecedented pressure on organizations and leaders, and leader behaviour and leadership processes are expected to have undergone compatible changes, rendering them no longer able to be completely understood within the paradigm of theories that were developed in the last century. This is also probably true for transformational leadership theory, which had found sound application as most large western companies, such as AT\&T, IBM, and GM, had ventured into transformations, and had comprehensively created changed programs which had to be realized in a relatively short time.

\section{Innovation}

Diverse definitions of innovation have been proposed (e.g., Knight, 1967; Zaltman, Duncan, \& Holbek, 1973). According to Knight (1967), innovation involves adoption of change that is about something new. One of the first definitions is that of Zaltman et al. (1973: 10), who explained innovation as 
"any idea, practice, or material artifact perceived to be new by the relevant unit of adoption". Within an organizational context, innovation is the creation of valuable and useful new products/services (Woodman, Sawyer, \& Griffin, 1993). This approach is consistent with Damanpour's (1991: 561) definition of product innovations as "new products/services introduced to meet an external user or market need," and the description provided by the OECD (2004: 64) as "the successful bringing of the new product or service to the market." Black and Lynch (2005) argued for a more specific working definition of organizational innovation for US firms that includes the following components - workforce training, employee voice, work design (including the use of crossfunctional production processes) and shared rewards. Birkinshaw, Hamel and Mol (2008, p. 829) define management innovation as the generation and implementation of a management practice, process, structure or technique that is new to the state of the art and is intended to further organizational goals. Well known examples of management innovation are lean production (introduced by Toyota) and brand management, developed by Procter and Gamble (Birkinshaw et al., 2008).

In today's globalized economic environment, intense competition and quantum acceleration in technological advancement, along with shortening product lifecycles, have made it imperative for firms to renew themselves. Firms' growth is found to depend upon its market orientation and firm innovation (Hurley \& Hult, 1998; Damanpour \& Gopalakrishnan, 2001; Bello, Lohtia, \& Sangtani, 2004). Firms are finding it crucial not only to offer new products and services, but also to change the nature of management styles. Early studies such as the work of Chandler (1962) and, more recently, Birkinshaw et al. (2008) clearly show how management innovation may not only change an organization and bring potential benefits to it, but also redefine an industry by influencing the spread of new ideas. According to Porter (1990), there has been a transition toward innovation-driven companies and competition has shifted largely toward sustainable and consistent innovation. 
Owing to the importance of innovation for sustainability and survival in a globally competitive environment, it is important to understand, in greater detail, the nature and characteristics of the concept. There are different types of innovations that organizations can pursue, and these are discussed in the next section.

\subsection{Radical and Disruptive Innovation}

Innovation can be incremental or radical. Incremental innovation is based on extending existing technologies and improving features of existing products, services and processes, whereas radical innovation is about creating dramatic change in technology, processes, products or services and ultimately transforming the existing markets and industry, or giving rise to new markets (Miller, Miller \& Dismukes 2006). Disruptive innovations are those that are based on developing new products or services, either in an incremental or a radical manner, but disseminating them through first introducing them to the lower end of the value chain and then moving upwards (Christenson, Raynor, \& McDonald, 2016).

The digitization of society and organizations has led to an increase in radical and disruptive innovations across all industries and trades (Yoo, Henfridsson, \& Lyytinen, 2010). Organizational innovation has to be adopted to fit these turbulent environments, requiring a shift from traditional, incremental innovation patterns to more radical approaches (Danneels, 2002). Radical or disruptive innovations are primarily those that have the power to upset the existing market dynamics and transform customer expectations by catering to needs that even the customers may not have been aware of initially. For example, cordless telephones were a radical innovation relative to wired phones because they were based on a substantially new technology; DVD players provide another example, as they used optical technology as opposed to the magnetic technology used in VCRs. In both these examples, the radical change was caused by technological breakthroughs that delivered much greater value to the customer than was possible via the earlier products. 
Radical innovations are important because they provide exponential opportunities for growth for the innovating firms, and threaten the very existence of laggards and push them out of the market. Also, according to numerous studies and scholars, companies eventually become stagnant and obsolescent if they do not introduce more than mere incremental innovations (Govindarajan and Kopalle, 2006a, b; McGrath, 2001; Utterback, 1994). Research on digital innovations has demonstrated the immense possibilities of disruptive innovations, either through building on newly developed technologies or developing new business cases for existing technologies. Radical product innovations are based on emerging or new technology, while disruptive innovations may not involve new technology, but may have the capacity to disrupt the way customers perceive or experience the product. While radical innovations can be targeted at both existing mainstream or emerging markets, disruptive innovations are typically targeted at an emerging market. Typical of disruptive innovation is its trajectory from emerging to mainstream markets; while it can initially only satisfy an emerging market, as the technology improves, its performance becomes sufficient to appeal to the mainstream market. Also, disruptive innovations are often novel in concept as well as feature, making them difficult for the masses to adopt and only favoured by innovators or early adopters (Christenson et al., 2016).

Christensen et al. (2016) discussed the distinction between low-end disruptions and new-market disruptions. Low-end disruptions, to begin with, involve cheaper, simpler and more convenient alternatives to existing products, whereas new market disruptive innovations initially address new markets and new customers and gradually disrupt the mainstream market. Amazon.com is an excellent depiction of low-end disruption which has gradually disrupted the traditional book stores market. On the other hand, the iPad has attracted new customers (people who wanted to have bigger screens, as well as the utility of a PDA) and slowly competed against laptops (mainstream customers who wanted laptops that could be carried around).

Another aspect of disruptive innovation is Reverse Innovation. Govindarajan and Trimble (2012) state that it would be imperative for companies not only to get good at innovating in emerging markets, but also to 14 
learn how to bring these innovations back to their core markets. Govindarajan, Kopalle and Danneels (2011) empirically examined the effects of mainstream and emerging customer orientation on radical and disruptive innovation, using data on 128 SBUs from 19 major corporations. They concluded that radical innovation may be accepted and adopted by mainstream customers who like to stay with existing products but desire greater value. On the other hand, these same customers may not be inclined to try disruptive innovations. Christensen and his colleagues have propounded the role of disruptive innovation in bringing about positive social change (Christensen, Bauman, Ruggles, \& Sadtler, 2006), in education (Christensen, Horn, \& Johnson, 2008) and in health care (Christensen, Grossman, \& Hwang, 2009).

Christensen (1997), who is an architect and a worldwide authority on disruptive innovations, developed a model that provides the rationale for the inability of well-managed, industry-leading companies to stay atop their industry when challenged with new, ground-breaking technological innovations. Christensen (1997) explains how established, successful companies leave themselves vulnerable to competition from upstarts by abandoning the lower end of the market. His model provides managers with insight about why companies that are competitive, listen to their customers, and invest aggressively in new technologies still end up losing market dominance due to a start-up with a disruptive innovation.

To sustain their competitive edge and business success, organizations' senior leadership must focus their time and resources on disruptive innovations. Studies have shown that using disruptive theory can significantly impact business success (Raynor, 2011). While the literature has often thought of radial innovation and disruptive innovation as contradictory, firms are able to pursue and benefit from both orientations. Disruptive innovation can be further studied in correlation to transformational leadership and organization performance.

\subsection{Ambidextrous Innovation / Dual Innovation}


Ambidexterity, in business terms, refers to the approach that enables an organization to place a stronghold on its existing businesses, products and processes on the one hand, and on the other hand, to invest in futuristic opportunities (García-Lillo, Úbeda-García \& Marco-Lajara, 2017; Trauffler \& Tschirky, 2006). Firms that have ambidextrous tendencies are able to maintain a stronghold in their existing markets as well as target emerging markets for a long-term future. Such organizations are able to balance multiple priorities and can develop targeted innovations that improve the efficiencies or effectiveness of their existing business processes or products; as well as drive innovation that is based on creative assessment of future technologies or future customer needs (Trauffler \& Tschirky, 2007; Yang, Zhou, \& Zhang, 2015).

Ambidextrous innovation is able to occur when companies follow a dual approach to their growth, focusing on both their present and the future (Durisin \& Todorova, 2012). They follow a DMASI (Define, Model, Abstract, Solve, Implement) framework for Tactical Innovation, which is aimed at solving current problems and preserving the current market position of the company (Chang, Chen, Chi, \& Lee, 2014). This framework allows the companies to invest time and resources in continuous incremental innovation of their existing businesses or products. The DMAPI (Define, Map, Apply, Plan and Implement) approach is followed to evolve and innovate for the future in a strategic manner. This framework allows the companies to think of disruptive and out-of-the-box ideas that can carry them in completely different directions and in different emerging markets (Güttel \& Konlechner, 2009).

Ambidextrous Innovation is therefore occurring at both the tactical level and the strategic level (Martin, Javalgi, \& Cavusgil, 2017), and often strategiclevel innovation also derives continuous innovation at the current and tactical level (Burgelman, Maidique, \& Wheelwright, 2004). Ambidextrous innovation or dual innovation allows organizations to conduct different types of innovations simultaneously, but this can happen only if the organizations have a culture that allows for ambidexterity and ambiguity (Taródy, 2016). This is because most organizations may possess either the capabilities to improve their current businesses, or what is referred to as conducting incremental 16 
innovation; or they possess the skills, mindsets and capabilities to conduct radical or disruptive innovations (Raisch, Birkinshaw, Probst, \& Tushman, 2009). It is difficult to reconcile to having both sets of capabilities, skills and mindsets within the same organization (Pérez-Luño, Wiklund, \& Cabrera, 2011; Kamaşak \& Bulutlar, 2010).

According to Chang et al. (2014), there are three dimensions searching ambidexterity, commitment ambidexterity, and learning and structure ambidexterity - that form the basis of ambidextrous innovation capabilities of an organization. Also, factors like creative support, corporate entrepreneurship and contingency reward play a role in establishing an environment of searching, commitment, and learning, and structure ambidexterity (Chang et al., 2014). These findings distinctly place organizations that have a conducive and facilitating culture as capable of developing ambidextrous innovations. In addition, leadership that allows for both freedom (to imagine futuristic product or process ideas) and stability (to preserve or enhance current efficiencies and effectiveness in products and processes) is able to usher in a culture of continuous innovation (Hughes, Martin, Morgan, \& Robson, 2010; Grover, Purvis, \& Segars, 2007).

\subsection{Design Thinking}

Design Thinking is an approach to innovation that places the customer or the end-user at the centre. It is based on the ideology that innovation needs to be solution-based, rather than problem-based (Beckman \& Barry, 2007). The process of product or idea development begins with the customers' needs or wants (Lockwood, 2010), rather than the expectations or aspirations of the company. Companies that employ this approach to innovation spend considerable amounts of time observing their current or potential customers in their natural environment and trying to identify the problems that the customers face while using the existing models of products.

These problems are recognized, data collected on the antecedent conditions for the problems in order to arrive at the core customer needs, and then the information and data is subjected to intense brainstorming sessions 
with customers and other stakeholders to arrive at possible solutions (Plattner, Meinel, \& Leifer, 2010; Plattner, Meinel, \& Weinberg, 2009). The idea behind design thinking is to develop products that serve to solve the problems of the customers as envisaged by the customers (Tschimmel, 2012). This approach requires the use of logic and systemic reasoning but mixed with intuitive reasoning and imagination, so that the customer-centric solutions can be innovated (Johansson-Köldberg, Woodilla, \& Çetinkaya, 2013).

Design thinking involves using design methodologies within a framework that requires conducting observations of real-life situations and scenarios and then developing opportunities to serve needs or provide solutions that would make the end users' lives better. This approach to innovation involves gathering data on an unmet need, discovering patterns or insights, discarding assumptions and defining scope, and then incubating all the ideas for some time before indulging in experimentation (Thoring \& Müller, 2011). This stage of experimentation is followed by refinement of ideas and development of prototypes that can be tested and sequentially iterated to improve. The end design of the product is expected to capture the thoughts and ideas that could provide customers with relief and delight (Beckman \& Barry, 2007; Thoring \& Müller, 2011). This approach to innovation is therefore driven by the customer orientation and requires the organization's culture and leadership to be customer-centric (Wylant, 2008).

The underlying idea behind using design thinking principles and strategy for innovation is to create products that are more desirable and appealing, and not just better in functionality or utility. However, this is only achievable if the organization has a design thinking mindset, which in turn requires it to establish a culture of creativity where people are allowed to spend time in thinking and imagining solutions (Neumeier, 2009; Ogilvie \& Liedtka, 2011). The crux of designing lies in the ability to create and visualize solutions that can serve the customers best (Cross, 2011).

In organizations that foster creativity, open communications and knowledge sharing, the design thinking approach is facilitated and found to 
lead to greater scope for innovation. Design thinking firms are continuously involved in thinking up new and better design for almost all of their operations and processes, which provides an impetus to innovation (Lockwood, 2010). The design way of thinking is therefore applicable to solving complex problems and results in creative outcomes for innovation (Lockwood, 2010). Research by the Design Management Institute has shown that companies that have design thinking at their core - like Coca Cola, Apple, Whirlpool, IBM and Procter and Gamble - have been consistently outperforming on S\&P 500 by $219 \%$ in the past decade (Naiman, 2018).

\subsection{Open Innovation and Crowd sourcing}

Open innovation and crowd sourcing are somewhat similar approaches to innovation, with a few differences. In the case of open innovation, an organization may encourage its employees, suppliers, partners, community, or even its rivals within the same industry, to contribute innovative ideas and get a diverse perspective on any given problem (Elmquist, Fredberg, \& Ollila, 2009). This enables the company to leverage ideas or intellectual properties from external sources and hence expand its own capacity to innovate (Chesbrough \& Garman, A2009). This type of innovation is facilitated by developing a culture of knowledge sharing within the stakeholders of the organization, and a collaborative approach to leadership and management (Gassmann, Enkel, \& Chesbrough, 2010).

In the case of crowd sourcing, the process is left open to the general public, who are invited to make their contributions in an open manner (Estellés-Arolas \& González-Ladrón-De-Guevara, 2012). In crowd sourcing, while the scope of generating ideas and reaching out to a very large number of people is high, it remains a low-level engagement and collaboration approach. Also, it is not expected to lead to genuine, authentic or even relevant collaboration of the public with the company (Dahlander \& Gann, 2010; Poetz \& Schreier, 2012; Enkel et al., 2009).

In open innovation, therefore, the company has some degree of choice in who participates in the innovation, while in crowd sourcing the company 
loses this control (Leimeister, Huber, Bretschneider, \& Krcmar, 2009; Sloane, 2011). Open innovation makes more sense when the company needs solutions for its own internal processes or wants to improve its internal efficiencies, as in the case of making its product development process more efficient (Brabham, 2013). The industry players or the company's own employees may have more creative and relevant ideas when it comes to the need for technical innovation in internal work processes. On the other hand, crowd sourcing is more lucrative if the innovation is targeted at developing better products that provide solutions to customers' needs (Schenk \& Guittard, 2011; Seltzer \& Mahmoudi, 2013).

\subsection{Lean Innovation}

Lean innovation, as the phrase suggests, is innovation that is brought about by processes that essentially save time, money and human capital, and which lead to products development via a process of waste elimination (Sehested \& Sonnenberg, 2011). Such innovation is possible when the company is open to capturing and accepting customer feedback early on and investing in experimentation and testing of novel products at a rapid pace (Schuh, Lenders, \& Hieber, 2011). The product development cycle is short and efficient and uses continuous and incremental improvements to perfect the process, instead of investing extensive time and money early in the development stage (Dombrowski, Zahn, \& Schulze, 2011). Lean innovation actually deploys design thinking to identify a variety of new opportunities to improve products or processes, and then to develop a prototype using minimal resources (Hoppmann, 2009; Sehested \& Sonnenberg, 2010).

This prototype or the early basic version of the product is deployed in a beta phase and customers' and other stakeholders' data is obtained to make continuous incremental improvements. Lean innovation therefore allows the companies to develop and test several ideas before they can invest their full energies and time in developing the winner (Hoppmann, Rebentisch, Dombrowski, \& Zahn, 2011). The process of developing products at a faster pace with less time and resource investment, however, requires changing 
work culture and business processes. Organizations that are able to carry out lean innovation are seen to have established protocols that reduce the need for bureaucratic approval (Marion \& Friar, 2012). They also deploy strategies like Six Sigma to facilitate the process of innovation (Byrne, Lubowe \& Blitz, 2007; Näslund, 2008). As such, lean innovation not only leads to the development of innovative products at a faster pace, but also can lead to change in the internal work culture of the organization.

\subsection{Three Horizon Model}

This approach from McKinsey and Company allows companies to invest in innovation-related projects based on their maturity level and the associated risks (Kerr, 2016). According to this model, three horizons are to be taken into account (Aghion, 2016). The first horizon is where core innovation occurs, and the organization focuses on steady, incremental improvements to its established products. In Horizon 1, the focus is predominantly on innovation that could increase efficiencies or reduce costs so that more value can be delivered to the customers through better versions of the same product (Gilbert, Smith, \& Sutherland, 2015). Horizon 2 is where the company wants to innovate in order to develop newer products that might replace its existing ones in a more profitable or sustainable manner (Curry \& Hodgson, 2008). This innovation is geared towards creating additional revenue generation streams and is reflective of the company's need to remain future-focused (McNichol, 2006; Schultz, 2006). Horizon 3 requires the company to push out of its comfort zone, move away from its present day constraints, embrace risks and invest in innovation that is non-aligned with its existing products or services (Slaughter, 2004). This horizon requires the organization to generate a large number of ideas that are developed into prototypes and tested against market risks and customer acceptance, and then iterated upon to develop better products (Giesen, Berman, Bell, \& Blitz, 2007). This type of innovation again requires a leadership mindset that is visionary, and where leaders are able to feel comfortable in ambiguity and look at challenges as opportunities (Barsh, Capozzi, \& Davidson, 2008). 


\section{Transformational Leadership and Innovation}

Leadership style has been underlined as one of the most important individual influences on firm innovation because leaders can directly decide to introduce new ideas into an organization, set specific goals, and encourage innovation initiatives from subordinates (Harborne \& Johne, 2003; McDonough, 2000; Sethi, 2000). Also, researchers have found that organizational structure and leadership roles are key factors in the discovery, incubation, and implementation of innovations (O'Connor \& DeMartino, 2006). Numerous other research findings have considered leadership as one of the organizational attributes underlying change and innovation (Chandler, 1962; Kanter, 1984; Peters and Waterman, 1984), and hence provide incentive for further exploration of this link in the context of the $21^{\text {st }}$ Century. Also, several scholars have focused on understanding the impact of different leadership styles and have highlighted it as an especially important influence on innovation (Harborne \& Johne, 2003; Kanter, 1983; McDonough, 2000; Sethi, 2000). It is the leadership style that creates the appropriate climate for entrepreneurship and innovation in an organization. Leaders can direct employees' efforts by articulating a vision that emphasizes long-term over short-term business outcomes and steers them towards innovative work processes and outcomes (Amabile, 1996)

A considerable amount of literature is available on transformational leadership and its impacts on innovation and organizational performance (Howell \& Avolio, 1993). For example, Sosik, Kahai, Jung, and Avolio (1998) found the transformational leadership had a positive impact on followers' creativity in a computer-mediated brainstorming exercise. Keller (1992) also found that transformational leadership positively influenced the performance of research and development (R\&D) project teams in a large $R \& D$ organization, enhanced subordinate innovativeness and impacted on the extent to which their innovative orientation added unique value to the projects that they finished. As per the study of 32 Taiwanese companies by Jung, $\mathrm{Wu}$, and Chow (2008), a direct and positive relationship exists between transformational leadership and organizational innovation. 
Other scholars have found that transformational leaders play a significant role in shaping firms' potential to generate innovations by encouraging an appropriate environment and making decisions that promote successful generation and implementation of knowledge (Kanter, 1983; Van de Ven, 1993). Furthermore, transformational leaders may also influence management innovation by reducing the uncertainty and complexity associated with its pursuit (Birkinshaw et al., 2008) by communicating a shared vision, supporting change, and developing a certain type of organizational culture. Sosik, Avolio, \& Kahai (1997) found evidence that as compared to other leadership types, transformational leadership was more effective at encouraging followers to think "out of the box" and to adopt generative and exploratory thinking processes that yielded more creative ideas and solutions. A similar finding has been reported by several other scholars, where innovation was linked to transformational leadership style and adaptive leadership behaviours (Howell \& Avolio, 1993; Lowe, Kroeck, \& Sivasubramaniam, 1996; and Gardner \& Avolio, 1998;). Transformational leadership is more often linked to successful innovation than is transactional leadership (Dess \& Picken, 2000). Transformational leadership is also found to be linked with greater job related satisfaction and higher motivation (Manz, Barstein, Hostager, and Shapiro, 1989).

Another area of research has been to study the leadership style or successful CEOs who have led their companies to innovation. While leaders often encourage creative thoughts and promote innovation by interacting with followers (e.g., challenging their long-held assumptions regarding their work approaches), CEOs may influence innovation in yet other ways. Successful CEOs like Jack Welch of General Electric and Lou Gerstner of IBM have emerged as role models of how adaptive leaders can successfully restructure and transform their organizations. Qualcomm and 3M are examples of companies that challenge their employees and empower them to be continuously innovative (Sosik, Jung, Berson, Dionne, \& Jaussi, in press). Hence, transformational leadership behaviours closely match the determinants of innovation and creativity in the workplace, some of which are vision, support for innovation, autonomy, encouragement, recognition, and 
challenge (Elkins and Keller, 2003). Researchers have also found that transformational leaders may have a positive influence on the market success of innovations, as these leaders articulate a strong vision of innovation and display a sense of power and confidence which helps them mobilize their followers to ensure the innovations' success in the longer term (Marion and Uhl-Bien, 2001).

\section{Conclusion and Areas for Further Studies}

As seen from the above discussion, there is clear indication that innovation is probably one of the most relevant, needed and measurable outcomes of transformational leadership. While several studies have found empirical evidence to support the correlation between transformational leadership style and positive organizational outcomes, including innovation, these studies do not delve deeper into the antecedent, mediating or moderating factors that may be acting upon the link between leadership and innovation (Mumford, Schultz, \& Osborn, 2002). More often than not, scholars have tried to develop a rationale for why transformational leaders may be more successful, based on the premises inherent in the transformational theory. For example, proponents of transformational leadership assert that by means of their behaviour, transformational leaders create personal and professional commitment from subordinates toward higher-level needs like self-esteem and self-actualization (Bass, 1985; Gardner \& Avolio, 1998). Burns (1978) introduced the transformational leadership theory, which was further developed by Avolio and Bass (1995). According to them, transformational leadership has four components: charismatic role modelling, individualized consideration, inspirational motivation, and intellectual stimulation. Several explanations support the expectation that transformational leadership would enhance employee creativity and innovation. 'Intellectual stimulation' exhibited by transformational leaders can facilitate unconventional and innovative thinking and working processes that lead to new knowledge and technology, which is fundamental to firm innovation (Dougherty \& Hardy, 1996). Transformational Leaders are able to 
share the risk of innovation with their followers through using idealized influence (Bass, Avolio, Jung, \& Berson, 2003). By empowering employee, they enable them to challenge existing way of things and innovate (Bass \& Avolio, 1994). Transformational leaders can also provide inspirational motivation and enable team working and participation (Sosik et al., 1997; Bass et al., 2003). It is also contended that transformational leaders perceive their role more as one of coordination, rather than command and control (Barczak \& Wilemon, 1992). Such leaders may also contribute to reducing complexity by getting others to rally around them in the pursuit of management innovation (Marion \& Uhl-Bien, 2001), underscoring their credentials as change agents.

It is evident from the available research that has been directed at establishing the effectiveness of transformational leaders on organizational innovation that there is a lack of research focus on exploring the dynamics of this relationship, especially when there is a need to refine the transformational theory itself. There is a gap in available understanding about the mechanism through which leadership may be enabling innovation and driving organizational performance: a gap that future research can endeavour to fill. In the context of the 21 st century, future research could also critically analyse the available literature on leadership, innovation, and organizational performance, and the dynamics between these three constructs. 


\section{References}

Argyris, C. (1957) Personality and Organization. New York: Harper.

Aghion, P. (2016). Moving to the Innovation Frontier. Competitiveness and Growth Policy Design. University of St. Gallen.

Amabile, T. M. (1996). Creativity in Context: Update to the Social Psychology of Creativity., Boulder, CO: Westview Press.

Argyris, C. (1962). Interpersonal Competence and Organizational Effectiveness. Homewood, Ill.: Dorsey Press.

Argyris, C. (1964). Integrating the Individual and the Organization. New York: Wiley.

Avolio, B.J., \& Bass, B.M. (1995). Individual consideration viewed at multiple levels of analysis-A Multilevel framework for examining the diffusion of transformational leadership. Leadership Quarterly, 6, 199-218.

Barczak, G., \& Wilemon, D. (1992), Successful new product team leaders. Industrial Marketing Management, 21, 61 - 68

Barsh, J., Capozzi, M.M., \& Davidson, J. (2008). Leadership and Innovation. McKinsey and Company. Retreived from: https://www.mckinsey.com/businessfunctions/strategy-and-corporate-finance/our-insights/leadership-and-innovation Bass, B. and Avolio, B. (Eds.) (1994). Introduction. Improving Organizational Effectiveness through Transformational Leadership. Thousand Oaks, CA: Sage Publications Inc.

Bass, B. M. (1985). Leadership and Performance Beyond Expectations. New York: Free Press.

Bass, B. M., \& Steidlmeier, P. (1999). Ethics, character, and authentic transformational leadership behavior. Leadership Quarterly, 10(2), 181-217. Bass, B.M. (1990). Bass and Stogdill's Handbook of Leadership: Theory, Research, and Managerial Applications (3rd ed.) New York: Free Press.

Bass, B.M., Avolio, B.J., Jung, D.I., \& Berson Y. (2003). Predicting unit performance by assessing transformational and transactional leadership. Journal of Applied Psychology, 88(2), 207-218.

Beckman, S. L., \& Barry, M. (2007). Innovation as a learning process: Embedding design thinking. California Management Review, 50(1), 25-56.

Bello, D. C., Lohtia, R., \& Sangtani, V. (2004). An institutional analysis of supply chain innovations in global marketing channels. Industrial Marketing

Management, 33(1), 57-64.

Bernard, L.L. (1926). An Introduction to Social Psychology. New York: Holt. Bingham W.V., \& Davis W.T. (1927). Leadership, in the Psychological Foundations. Metcalf H.E. (Ed.). New York, NY, Shaw, pp. 56-74.

Birkinshaw J, Hamel G, \& Mol M (2008). Management innovation. Academy of Management Review, 33(4), 825-845.

Black, Sandra E., \& Lisa M. Lynch, (2005). Measuring Organizational Capital in the New Economy. In Corrado, C., Haltiwanger, J., \& Sichel, J. (Eds.), Measuring Organizational Capital in the New Economy. University of Chicago Press. 
Blake, R.R., \& Mouton, J.S. (1964). The Managerial Grid. Houston: Gulf Publishing.

Boamah, S. A., Laschinger, H. K. S., Wong, C., \& Clarke, S. (2018). Effect of transformational leadership on job satisfaction and patient safety outcomes. Nursing Outlook, 66(2), 180-189.

Bogardus, E.S. (1934). Leaders and Leadership. New York: Appleton-Century. Bolden, R., Gosling, J., Marturano, A., \& Dennison, P. (2003). A review of leadership theory and competency frameworks. Centre for Leadership Studies. University of Exeter.

Brabham, D. C. (2013). Crowdsourcing. John Wiley and Sons, Inc.

Burgelman, R., Maidique, M., \& Wheelwright, S. (2004). Strategic Management of Technology and Innovation. McGraw-Hill Publishing.

Burns, J. M.(1978). Leadership. New York: Harper and Row.

Byrne, G., Lubowe, D., \& Blitz, A. (2007). Using a Lean Six Sigma approach to drive innovation. Strategy and Leadership, 35(2), 5-10.

Caniëls, M. C., Semeijn, J. H., \& Renders, I. H. (2018). Mind the mindset! The interaction of proactive personality, transformational leadership and growth mindset for engagement at work. Career Development International, 23(1), 48-66. Chandler, A.D. (1962). Strategy and Structure: Chapters in the History of the American Industrial Enterprise. MIT Press, Cambridge.

Chang, Y. C., Chen, M. H., Chi, H. R., \& Lee, H. F. (2014, July). Ambidextrous innovation capabilities, antecedents and performance in Portland International Center for Management of Engineering and Technology (PICMET), 2014 Portland International Conference, IEEE. (pp. 840-850).

Chesbrough, H. W., \& Garman, A. R. (2009). How open innovation can help you cope in lean times. Harvard Business Review, 87(12), 68-76.

Christensen, C. M. (1997). The Innovator's Dilemma: When New Technologies Cause Great Firms to Fail. Boston: Harvard Business School Press.

Christensen, C. M., Raynor, M. E., \& McDonald, R. (2016). What is disruptive Innovation. The Encyclopedia of Human-Computer Interaction. (2nd ed.) Retrieved from: https://www.interaction-design.org/literature/book/theencyclopedia-of-human-computer-interaction-2nd-ed/disruptive-innovation

Christensen, C., Bauman, H., Ruggles, R., \& Sadtler, T. (2006). Disruptive innovation for social change. Harvard Business Review, December 2006, 94-101. Christensen, C., Grossman, J., \& Hwang, J. (2009). The Innovator's Prescription: A Disruptive Solution for Health Care. New York, NY: McGraw-Hill.

Christensen, C., Horn, M., \& Johnson, C. (2008). Disrupting Class: How

Disruptive Innovation will Change the Way the World Learns. New York, NY: McGraw-Hill.

Cross, N. (2011). Design Thinking: Understanding how Designers Think and Work. Berg.

Curry, A., \& Hodgson, A. (2008). Seeing in multiple horizons: connecting futures to strategy. Journal of Futures Studies, 13(1), 1-20.

Dahlander, L., \& Gann, D. M. (2010). How open is innovation? Research Policy, 39(6), 699-709. 
Damanpour, F. (1991). Organizational Innovation: A Meta-analysis of Effects of Determinants and Moderators. The Academy of Management Journal, 34: 555590.

Damanpour, F., \& Gopalakrishnan, S. (2001), The dynamics of the adoption of product and process innovations in organizations. The Journal of Management Studies, 38(1), 45-65.

Danneels, E. (2002). The dynamics of product innovation and firm competences. Strategic Management Journal, 23(12), 1095-1121.

Dess, G.G., \& Picken, J.C. (2000). Changing roles: Leadership in the 21 st century. Organizational Dynamics, 28(3), 18 - 34.

Dombrowski, U., Zahn, T., \& Schulze, S. (2011, March). State of the Art-Lean Development. In Proceedings of the 21 st CIRP Design Conference.

Dougherty, D., \& C. Hardy. (1996). Sustained product innovation in large, mature organizations: Overcoming innovation-to-organization problems. Academy of Management Journal, 39, 1120-1153.

Dowd, J. (1936) Control in Human Societies. New York: Appleton-Century. Downton, Jr., J.V. (1973). Rebel Leadership: Commitment and Charisma in the Revolutionary Process. New York: Free Press.

Durisin, B., \& Todorova, G. (2012). A study of the performativity of the "ambidextrous organizations" theory: Neither lost in nor lost before translation. Journal of Product Innovation Management, 29(S1), 53-75.

Eberly, M.B., Bluhm, D.J., Guarana, C., Avolio, B.J., \& Hannah, S.T. (2017). Staying after the storm: How transformational leadership relates to follower turnover intentions in extreme contexts. Journal of Vocational Behavior, 102, 72 85.

Elkins, T. \& R.T. Keller (2003). Leadership in research and development organizations: A literature review and conceptual framework. The Leadership Quarterly, 14(4-5): 587-606.

Elmquist, M., Fredberg, T., \& Ollila, S. (2009). Exploring the field of open innovation. European Journal of Innovation Management, 12(3), 326-345.

Enkel, E., Gassmann, O., \& Chesbrough, H. (2009). Open R\&D and open innovation: exploring the phenomenon. $R \& D$ Management, 39(4), 311-316. https://doi.org/10.1111/j.1467-9310.2009.00570.x

Estellés-Arolas, E., \& González-Ladrón-De-Guevara, F. (2012). Towards an integrated crowdsourcing definition. Journal of Information Science, 38(2), 189200.

Evans, M.G. (1970). The effect of supervisory behavior on the path-goal relationship. Organizational Behavior and Human Performance, 5, 277-298. Fiedler, F.E., Chemers, M.M., \& Mahar, L. (1976). Improving Leadership Effectiveness: The leader Match Concept. New York: John Wiley and Sons. Fiedler, FE. (1967). A Theory of Leadership Effectiveness. New York: McGrawHill.

Fisher, B.A. (1986). Leadership, When does a difference make a difference? In Hirokawa, R.Y., \& Poole, M.S. (Eds.), Communication and Group DecisionMaking. (pp. 197-215) Beverly Hills: Sage. 
Freud, S. (1921). Group Psychology and the Analysis of the Ego. In A general selection from the works of Sigmund Freud, Rickman, J. (Ed.). London: Hogarth. Fromm, E. (1941). Escape from Freedom. London: Routledge.

García-Lillo, F., Úbeda-García, M., \& Marco-Lajara, B. (2017). Organisational ambidexterity: a literature review using bibliometric methods. International Journal of Bibliometrics in Business and Management, 1(1), 3-25.

ardner, W.L., \& Avolio, B.J. (1998). The charismatic relationship: A dramaturgical Perspective. Academy of Management Review, 23, 32-58. Gassmann, O., Enkel, E., \& Chesbrough, H. (2010). The future of open innovation. Randd Management, 40(3), 213-221.

Giesen, E., Berman, S. J., Bell, R., \& Blitz, A. (2007). Three ways to successfully innovate your business model. Strategy and Leadership, 35(6), 27-33.

Gilbert, D.H., Smith, A.C., \& Sutherland, F. (2015). Osmotic strategy: Innovating at the core to inspire at the edges. Organizational Dynamics, 44(3), 217-225.

Gilpin, R. (2018). The Challenge of Global Capitalism: The World Economy in the 21st Century. Princeton University Press.

Glor, E. D., \& Rivera, M. (2016). Assessing the Relationship between Innovation and Survival in Organizations: An Empirical Review, Research Synthesis, and Analytical Case Study. The Innovation Journal, 21(2), p. 1.

Goleman, D., Boyatzis, R. E., \& McKee, A. (2013). Primal leadership:

Unleashing the power of emotional intelligence. Harvard Business Press.

Govindarajan, V., \& Kopalle, P.K. (2006a), Disruptiveness of innovations:

Measurement and an assessment of reliability and validity. Strategic Management Journal, 27 (2): 189-99.

Govindarajan, V., \& Kopalle, P.K. (2006b). The usefulness of measuring disruptiveness of innovations ex-post in making ex-ante predictions. Journal of Product Innovation Management, 23 (1), 12-18.

Govindarajan, V., \& Trimble, C. (2012). Reverse innovation: Create Far from Home, Win Everywhere. Harvard Business Review Press.

Govindarajan, V., Kopalle, P. K., \& Danneels, E. (2011). The Effects of Mainstream and Emerging Customer Orientations on Radical and Disruptive Innovations. Journal of Product Innovation Management, 28(s1), 121-132. Grover, V., Purvis, R.L., \& Segars, A.H. (2007). Exploring ambidextrous innovation tendencies in the adoption of telecommunications technologies. IEEE Transactions on Engineering Management, 54(2), 268-285.

Güttel, W.H., \& Konlechner, S.W. (2009). Continuously hanging by a thread: Managing contextually ambidextrous organizations. Schmalenbach Business Review, 61(2), 150-172.

Harborne, P., \& Johne, A. (2003), Creating a project climate for successful product Innovation, European Journal of Innovation Management, 6(2), 118-132. Hersey, P., \& Blanchard, K. (1982). Management of Organizational Behavior: Utilizing Human Resources. Prentice-Hall: New Jersey.

Hocking, W.E. (1924), Leaders and led. Yale Review, 13, 625-641.

Hoppmann, J. (2009). The Lean Innovation Roadmap-A Systematic Approach to Introducing Lean in Product Development Processes and Establishing a Learning Organization (Doctoral dissertation). 
Hoppmann, J., Rebentisch, E., Dombrowski, U., \& Zahn, T. (2011). A framework for organizing lean product development. Engineering Management Journal, 23(1), 3-15.

House, R.J. (1971). Path-goal theory of leader effectiveness. Administrative Science Quarterly, 16, 321-338.

House, R.J. (1977). A 1996 Theory of Charismatic Leadership. In Leadership: The cutting edge. Hunt, J.G., \& Larson, L.L. (Ed.). Carbonale: The Southern Illinois University Press, 189-207.

Howell, J.M., \& Avolio, B.J. (1993). Transformational leadership, transactional leadership, locus of control and support for innovation: Key predictors of consolidated business unit performance, Journal of Applied Psychology, 78, 891902.

Hughes, M., Martin, S. L., Morgan, R. E., \& Robson, M. J. (2010). Realizing product-market advantage in high-technology international new ventures: The mediating role of ambidextrous innovation. Journal of International Marketing, 18(4), 1-21.

Hurley, R. F., \& Hult, G. T. (1998). Innovation, market orientation, and organizational learning: An integration and empirical examination. Journal of Marketing, 62, 42-54.

Jermier, J.M., \& Berkes, L.J. (1979). Leader behavior in a police command bureaucracy: a closer look at the quasi-military model. Administrative Science Quarterly, 24(1), 1-23.

Johansson-Sköldberg, U., Woodilla, J., \& Çetinkaya, M. (2013). Design thinking: past, present and possible futures. Creativity and Innovation Management, 22(2), 121-146.

Jung, D. D., Wu, A., \& Chow, C. W. (2008). Towards understanding the direct and indirect effects of CEOs' transformational leadership on firm innovation. The Leadership Quarterly, 19(5), 582-594.

Kamaşak, R., \& Bulutlar, F. (2010). The influence of knowledge sharing on innovation. European Business Review, 22(3), 306-317.

Kanter, R.M. (1983). The Change Masters. New York' Simon and Schuster. Kanter, R.M. (1984). The Change Masters. London: Unwin Hyman.

Keller, R.T. (1992), Transformational leadership and the performance of research and development project groups. Journal of Management, 18, 489-501.

Kerr, W.R. (2016). Innovation and Business Growth. Moving to the Innovation Frontier, 41.

Kilbourne, C.E. (1935). The element of leadership. Journal of Coast Artillery, 37, 45-48.

Knight, K. (1967). A Descriptive Model of the Intra-Firm Innovation Process. Journal of Business, 40, 478-96.

Kuhnert, K.W., \& Lewis, P. (1987). Transactional and Transformational Leadership: A constructive/developmental analysis. Academy of Management Review, 12, 648-657.

Larson, L.L, Hunt, J.G., \& Osborn, R.N. (1976). The Great hi-hi leader behavior myth: A lesson from Occams razor. The Academy of Management Journal, 19(4), 628-641. 
Laszlo, C., \& Cescau, P. (2017). Sustainable Value: How the World's Leading Companies are Doing Well by Doing Good. Routledge.

Lee, M. R. (2016). Leading Virtual Project Teams: Adapting Leadership Theories and Communications Techniques to 21st Century Organizations. Auerbach Publications.

Leimeister, J. M., Huber, M., Bretschneider, U., \& Krcmar, H. (2009). Leveraging crowdsourcing: activation-supporting components for IT-based ideas competition. Journal of Management Information Systems, 26(1), 197-224.

Lewis, E., Boston, D., \& Peterson, S. (2017). A Global Perspective of Transformational Leadership and Organizational Development. Journal of Research Initiatives, 2(3), 5.

Likert, R. (1967). The Human Organization - Its Management and Value. New York: McGraw- Hall.

Lockwood, T. (2010). Design Thinking: Integrating Innovation, Customer Experience, and Brand Value. Skyhorse Publishing, Inc.

Lowe, K.B., Kroeck, K.G., \& Sivasubramaniam, N. (1996). Effectiveness correlates of transformational and transactional leadership: A meta-analytic review. Leadership Quarterly, 7, 385 - 425.

Manz, C.C., Barstein, D.T., Hostager, T.J., \& Shapiro, G.L. (1989). Leadership and innovation: A longitudinal process view. In Van de Ven, A., Angle, H.L., \& Poole, M.S. (Eds.,) Research on the Management of Innovation: The Minnesota Studies. New York' Harper and Row.

Marion R., \& Uhl-Bien M. (2001). Leadership in complex organizations. The Leadership Quarterly, 12, 389-418.

Marion, T.J., \& Friar, J.H. (2012). Managing global outsourcing to enhance lean innovation. Research-Technology Management, 55(5), 44-50.

Martin, S.L., Javalgi, R.G., \& Cavusgil, E. (2017). Marketing capabilities, positional advantage, and performance of born global firms: Contingent effect of ambidextrous innovation. International Business Review, 26(3), 527-543.

Maslow, A.H. (1954). Motivation and Personality. New York: Harper.

McCall, M.W. (1998). High Flyers: Developing the Next Generation of Leaders. Harvard Business Press.

McDonough, E.F. (2000), Investigation of factors contributing to the success of cross-functional teams. Journal of Product Innovation Management, 17(3), 221235.

McGrath, R.G. (2001). Exploratory learning, innovative capacity, and managerial oversight. Academy of Management Journal, 44 (1), 118-31.

McGregor, D. (1960). The Human Side of Enterprise. New York: McGraw-Hill. McNichol, T. (2006). AC/DC: The Savage Tale of the First Standards War.

Chichester, UK: Wiley.

Miller, L., Miller, R., \& Dismukes, J. (2006). The Critical Role of Information and Information Technology in Future Accelerated Radical Innovation, Information, Knowledge System, Management. Research article, IOS Press, 5(2), 63-69.

Mintzberg, H. (1973). The Nature of Managerial Work. New Jersey: PrenticeHall. 
Mumford, M.D., Schultz, R.A., \& Osborn, H.K. (2002). Planning in organizations: Performance as a multi-level phenomenon. In Yammarino, F.J., \& Dansereau, F. (Eds.,) Research in Multi-Level Issues: The Many Faces of MultiLevel Issues. Elsevier, Oxford, 3-35.

Naiman, L. (2018). Design thinking as strategy for Innovation. Creativity at Work. Retrieved from: https://www.creativityatwork.com/design-thinkingstrategy-for-innovation/

Näslund, D. (2008). Lean, six sigma and lean sigma: fads or real process improvement methods? Business Process Management Journal, 14(3), 269-287. Neumeier, M. (2009). The Designful Company: How to Build a Culture of Nonstop Innovation. Peachpit Press.

O'Connor, G.C., \& DeMartino, R. (2006). Organizing for Radical Innovation: An Exploratory Study of the Structural Aspects of RI Management Systems in Large Established Firms. Journal of Product Innovation Management, 23, 475-497.

Ogilvie, T., \& Liedtka, J. (2011). Designing for growth: A design thinking toolkit for managers. Columbia University Press.

Organisation for Economic Co-operation and Development [OECD] (2004), Small and Medium-Sized Enterprises in Turkey: Issues and Policies. Paris: OECD.

Pérez-Luño, A., Wiklund, J., \& Cabrera, R. V. (2011). The dual nature of innovative activity: How entrepreneurial orientation influences innovation generation and adoption. Journal of Business Venturing, 26(5), 555-571. Peters, T.J., \& Waterman, R.H. (1984). In Search of Excellence. New York: Warner Books.

Plattner, H., Meinel, C., \& Leifer, L. (Eds.). (2010). Design Thinking: Understand-Improve-Apply. Springer Science and Business Media.

Plattner, H., Meinel, C., \& Weinberg, U. (2009). Design Thinking. Landsberg am Lech: Mi-Fachverlag.

Poetz, M. K., \& Schreier, M. (2012). The value of crowdsourcing: can users really compete with professionals in generating new product ideas? Journal of Product Innovation Management, 29(2), 245-256.

Porter, M.E. (1990). The Competitive Advantage of Nations. New York' The Free Press.

Raisch, S., Birkinshaw, J., Probst, G., \& Tushman, M.L. (2009). Organizational ambidexterity: Balancing exploitation and exploration for sustained performance. Organization Science, 20(4), 685-695.

Raynor, M. (2011). The Innovator's Manifesto: Deliberate Disruption for Transformational Growth. Crown Business.

Schaltegger, S., Lüdeke-Freund, F., \& Hansen, E. G. (2016). Business models for sustainability: A co-evolutionary analysis of sustainable entrepreneurship, innovation, and transformation. Organization and Environment, 29(3), 264-289. Schenk, E., \& Guittard, C. (2011). Towards a characterization of crowdsourcing practices. Journal of Innovation Economics and Management, (1), 93-107.

Schuh, G., Lenders, M., \& Hieber, S. (2011). Lean Innovation-Introducing value systems to product development. International Journal of Innovation and Technology Management, 8(01), 41-54. 
Schultz, W. (2006). The cultural contradictions of managing change: Using horizon scanning in an evidence-based policy context. Foresight, 8(4), 3-12. Sehested, C., \& Sonnenberg, H. (2010). Lean Innovation: A Fast Path from Knowledge to Value. Springer Science and Business Media.

Sehested, C., \& Sonnenberg, H. (2011). The Potential of Lean Innovation. In Lean Innovation, pp. 11-24. Springer, Berlin, Heidelberg.

Seltzer, E., \& Mahmoudi, D. (2013). Citizen participation, open innovation, and crowdsourcing: Challenges and opportunities for planning. Journal of Planning Literature, 28(1), 3-18.

Sethi, R. (2000). New product quality and product development team. Journal of Marketing, 64(2), 1-14.

Shapiro, J.P., \& Stefkovich, J.A. (2016). Ethical Leadership and Decision Making in Education: Applying Theoretical Perspectives to Complex Dilemmas.

Routledge.

Slaughter, R. (2004). Futures beyond Dystopia. London: RoutledgeFalmer.

Sloane, P. (2011). A Guide to Open Innovation and Crowdsourcing: Advice from Leading Experts in the Field. Kogan Page Publishers.

Sosik, J.J., Avolio, B J., Kahai, S S., \& Jung, D.I. (1998). Computer supported work group potency and effectiveness: The role of transformational and Transactional leadership, anonymity, and task interdependences. Computers in Human Behavior, 14, 491-511.

Sosik, J.J., Avolio, B.J., \& Kahai, S.S. (1997). Effects of leadership style and anonymity on group potency and effectiveness in a group decision support system environment. Journal of Applied Psychology, 82, 89 - 103.

Sosik, J.J., Jung, D., Berson, Y., Dionne, S.D., \& Jaussi, K.S. (in press). The Dream Weavers: Strategy-Focused Leadership in Technology-Driven Organizations. Greenwich, CT: Information Age.

Tang, L.L., \& Yeh, Y.L. (2013). The Effect of Organizational Culture, Leadership Style and Organizational Learning on Innovation Capability in Public Sector. doi: 10.6220/joq.2015.22(5).06

Taródy, D. (2016). Organizational ambidexterity as a new research paradigm in strategic management. Vezetéstudomány/Budapest Management Review, 47(5), 39-52.

Tead, O. (1935). The Art of Leadership. New York: McGraw-Hill.

Thoring, K., \& Müller, R.M. (2011). Understanding design thinking: A process model based on method engineering. In DS 69: Proceedings of E\&PDE 2011, the 13th International Conference on Engineering and Product Design Education, London, UK, 08.-09.09. 2011.

Tichy, N., \& Devanna, M. (1986). Transformational Leadership. New York: Wiley.

Trauffler, G., \& Tschirky, H. (2006). Sustained Innovation Management: Assimilating Radical and Incremental Innovation Management. Springer. Trauffler, G., \& Tschirky, H.P. (2007). Sustained innovation management. In Sustained Innovation Management (pp. 80-209). Palgrave Macmillan, London. Triana, M.D.C., Richard, O.C., \& Yücel, İ. (2017). Status incongruence and supervisor gender as moderators of the transformational leadership to subordinate 
affective organizational commitment relationship. Personnel Psychology, 70(2), 429-467.

Tschimmel, K. (2012, January). Design Thinking as an Effective Toolkit for Innovation. In Proceedings of Conference of The International Society for Professional Innovation Management [ISPIM]. (p. 1).

Tsvetkova, A., Thill, J. C., \& Strumsky, D. (2014). Metropolitan innovation, firm size, and business survival in a high-tech industry. Small Business Economics, 43(3), 661-676.

Utterback, J. M. (1994). Mastering the Dynamics of Innovation. Boston: Harvard Business School Press.

Van de Ven, A.H. (1993). Managing the process of organizational innovation. In Huber, G.P., \& Glick, W.H. (Eds.), Organizational Change and Redesign: Ideas and Insights for Improving Performance. (pp. 269 -294). New York Oxford University Press.

Vroom, V.H., \& Yetton, P.W. (1973). Leadership and Decision-Making (Vol. 110). University of Pittsburgh Press.

Woodman, R.W., Sawyer, J.E., \& Griffin, R.W. (1993). Toward a Theory of Organizational Creativity. Academy of Management Review, 18(2): 293-321. Wylant, B. (2008). Design thinking and the experience of innovation. Design Issues, 24(2), 3-14.

Yang, Z., Zhou, X., \& Zhang, P. (2015). Discipline versus passion: Collectivism, centralization, and ambidextrous innovation. Asia Pacific Journal of Management, 32(3), 745-769.

Yoo, Y., Henfridsson, O., \& Lyytinen, K., (2010), The new organizing logic of digital innovation: an agenda for information systems research. Information Systems Research, 21(4), 724-735.

Zaltman, G., Duncan, R., \& Holbek, J. (1973). Innovations and Organizations. New York: Wiley. 